УДК 37.017

\title{
ИСТОРИЧЕСКИЕ ОСОБЕННОСТИ РАЗВИТИЯ ПАТРИОТИЗМА В РОССИИ В ХІХ И ХХ ВЕКАХ КАК ОСНОВА ИДЕАЛОСООБРАЗНОСТИ ВОСПИТАНИЯ ЧЕЛОВЕКА
}

\author{
Хлызова Ирина Валерьевна \\ кандидат педагогических наук, \\ доцент кафедры педагогики \\ ГОУ ВО Московской области
} Московский государственный областной университет

\begin{abstract}
Аннотация: Раскрыты исторические особенности развития патриотизма в России в XIX и XX веках, как основа идеалосообразности воспитания человека. На основе анализа научной литературы обоснованы сущность и специфика патриотического воспитания человека. Выявлены направления воспитания патриотизма. Сделаны выводы о том, что совершенствование патриотического воспитания следует осуществлять путём развития высокой социальной активности, гражданской ответственности, духовности, активного вовлечения молодёжи в решение социально-экономических, культурных, правовых, экологических и других проблем общества.
\end{abstract}

Ключевые слова: Патриотизм, патриотическое воспитание, молодёжь, ценности патриотизма, идеалосообразность.

\section{HISTORICAL FEATURES OF THE DEVELOPMENT OF PATRIOTISM IN RUSSIA IN THE XIX AND XX CENTURIES, AS THE BASIS IDEALITY OF HUMAN EDUCATION}

Khlyzova Irina Valerevna candidate of pedagogical sciences

\begin{abstract}
Historical features of the development of patriotism in Russia in the XIX and XX centuries have been revealed, as the basis for the idealness of human education. Based on the analysis of scientific literature, the essence and specifics of patriotic education of a person are substantiated. Areas of education of
\end{abstract}


patriotism have been identified. It was concluded that the improvement of patriotic education should be carried out by developing high social activity, civic responsibility, spirituality, and the active involvement of youth in solving socioeconomic, cultural, legal, environmental and other problems of society.

Key words: Patriotism, patriotic education, youth, values of patriotism, idealness.

Проблема патриотического воспитания молодёжи является актуальной проблемой в современном российском обществе, и решать её сегодня на федеральном, муниципальном, региональном уровнях пытаются теоретики и практики в законодательстве и в различных научных областях. Данная проблема лежит на стыке таких наук, как педагогика, история, социология, философия, политология.

Упадок духовно-нравственных ценностей, отсутствие патриотических чувств у молодежи - тревожные особенности современной России. Данная ситуация влечёт за собой необходимость выполнения социального заказа по обновлению содержания воспитания в рамках разрешения данной проблемы.

Негативные процессы конца XX века повлекли за собой то, что у молодежи утрачены или разрушены традиционно-нравственные черты российского менталитета, складывающиеся веками.

Преобладают такие отрицательные качества, как отсутствие патриотизма, негативное отношение к старшему поколению. Наблюдается утрата таких чувств, как долг перед родителями, семьей, друзьями, обществом, Отечеством. За годы социально-политических образований выросло поколение молодежи, которое не знакомо с лучшими достижениями мировой и отечественной культуры.

Утратив патриотизм, а также связанные с ним национальную гордость и достоинство, мы минимизируем себя как народ, способный на великие свершения. Многовековая история России показывает, что без патриотизма невозможно создать сильную страну, привить людям желание выполнять свой гражданский долг и уважать закон.

Для поднятия уровня патриотизма в Российской Федерации необходимо обратить внимание на воспитательную работу с современной молодежью.

В последнее время молодежь стала упрощенно относиться к таким понятиям, как любовь к Родине, патриотизм, гражданский долг. Все чаще 
центральное место в их мировоззрении занимают материальные атрибуты успеха и образы, навеянные прямой агитацией СМИ: деньги, престижный уровень потребления и досуга. Данный процесс в будущем может стать причиной деградации общества.

В связи с вышесказанным, в России необходимо особое внимание уделять патриотическому воспитанию молодёжи в соответствии с изменениями, происходящими в обществе.

Воспитание патриотизма регламентируется «Конституцией РФ», законом РФ «Об образовании» и другими законами и подзаконными актами. Однако, практика показывает, что основные положения законов и подзаконных актов не реализуются. В России происходит процесс деморализации и денационализации современной молодежи, которая теряет не только национальное, но и человеческое лицо [1].

Особое значение приобретает целенаправленная и систематическая деятельность органов государственной власти и общественных организаций по формированию ценностей патриотизма, нравственности и культуры, возрождению идеи национальных патриотических традиций и ценностей России.

Сущность патриотического воспитания определяется в общей потребности россиян в сильном и могущественном государстве; восстановлении и укреплении национальных традиций, ценностей, идеалов; в сплочении всего народа на благо Родины, Отечества, человека; в духовнонравственном оздоровлении всех слоёв населения; в психологической готовности к любым испытаниям, трудностям во имя интересов каждого человека, народа России.

Идея возрождения национальных патриотических традиций и ценностей воплощается в процессе образования молодёжи и студентов.

В этом смысле патриотическое воспитание в рамках образовательного процесса направлено:

- на развитие в обществе духовности;

- на становление граждан, обладающих позитивными патриотическими ценностями и качествами, способных проявить их в созидательном процессе в интересах Родины; 


\section{ИННОВАЦИОННОЕ РАЗВИТИЕ НАУКИ: ФУНДАМЕНТАЛЬНЫЕ И ПРИКЛАДНЫЕ ПРОБЛЕМЫ}

- на воспитание у молодёжи мотивации служения своему народу и Отечеству; возрождение и формирование у населения православных ценностей;

- на формирование бережного отношения к культурному наследию народов России;

- на формирование бережного отношения к природе страны;

- на формирование бережного отношения к людям и природному окружению своей местности; истории и традициям;

- на усвоение лучших моральных и нравственных принципов, выработанных человечеством на протяжении многовековой истории;

- на усвоение и воплощение в жизнь нравственных традиций русского народа;

- на сохранение и приумножение патриотических ценностей общества;

- на гармоничное развитие каждой личности, привитие ей основополагающих принципов нравственности: честности, желания заботиться о ближнем, уважения к старшим, уважения к историческому прошлому страны;

- на формирование национального самосознания, ответственного отношения к русскому языку как государственному и как средству межнационального общения, уважения к родному языку.

Идея возрождения национальных патриотических традиций и ценностей России направлена на обновление нравственного идеала современного человека.

В современной России, когда нравственные идеалы прошлых веков постепенно утрачиваются, а новые идеалы выражены не чётко, проблема о формировании патриотических чувств человека звучит особенно актуально. В связи с этим, как считают многие современные учёные, необходимо усилить патриотическое воспитание молодёжи [2; $3 ; 4 ; 5]$.

Проблема патриотического воспитания молодежи уходит корнями глубоко в историю. Если рассмотреть исторические особенности развития патриотизма в России в XIX и XX веках, то можно выявить его некоторые закономерности. 


\section{ИННОВАЦИОННОЕ РАЗВИТИЕ НАУКИ: ФУНДАМЕНТАЛЬНЫЕ И ПРИКЛАДНЫЕ ПРОБЛЕМЫ}

Патриотическое воспитание молодёжи мы рассматриваем, как аспект идеалосообразности воспитания. Термин «деалосообразность воспитания» ввел П.Ф. Каптерев в 1895г. Под данным понятием он понимал некое соответствие тому или иному идеалу воспитания, сложившемуся в обществе в определённый период времени. С его точки зрения, идеалосообразное усовершенствование личности составляет саму сущность воспитательного процесса.

XIX век оставил глубокий след в истории педагогической мысли в России в аспекте воспитания патриотизма у молодого поколения. В это время прогрессивные мыслители, ученые, педагоги выступили с оригинальными, в высшей степени плодотворными мыслями по вопросам патриотического воспитания человека.

Освещением различных аспектов патриотического воспитания человека занимались видные представители прогрессивного педагогического движения XIX в.: В.Г. Белинский, Н.А. Добролюбов, Н.И. Пирогов, К.Д. Ушинский, Н.Г. Чернышевский и др.

Обладая специфическим взглядом на природу человека, педагоги ХІХв. считали, что обязанностью школы является обеспечение не только нравственного, эстетического, умственного, физического, но и патриотического воспитания человека, что является в целом идеалом воспитания человека.

Идеал воспитания человека в целом вбирает в себя особенности менталитета конкретного народа, базовые ценности, накопленные веками. Опираясь на исторические и национальные особенности народа, идеал воспитания человека включает в себя систему основополагающих ценностных координат, вмещающую опыт веков. На основе идеала воспитания человека прошлых столетий в соответствии с потребностями общества теория и практика современного воспитательного процесса задаёт определённые социальные требования к человеку, формирует современные цели и задачи воспитания, в том числе и патриотические.

Воспитание современной молодёжи основывается на идеалах воспитания предыдущих эпох и формируется под влиянием исторически сложившихся общественных условий и деятельности педагогов прошлых столетий. 


\section{ИННОВАЦИОННОЕ РАЗВИТИЕ НАУКИ: ФУНДАМЕНТАЛЬНЫЕ И ПРИКЛАДНЫЕ ПРОБЛЕМЫ}

Можно сказать, что идеал воспитания человека представляет собой ориентир в виде системы ценностных координат. Современный идеал воспитания человека, опираясь на ценности идеалов воспитания человека прошлых столетий вбирает в себя основополагающие патриотические ценности предыдущих эпох: гражданственность, уважение к правам и свободам человека, патриотизм, трудолюбие, ценность жизни и здоровья человека, стремление к улучшению жизни общества, гуманизм. Одновременно с этим, имея основополагающие ценности предыдущих эпох, современный идеал воспитания человека вбирает в себя патриотические ценности современной эпохи. Исходя из опроса молодёжи, такими ценностями являются: гражданственность, патриотизм, любовь к Родине.

Рассмотрим более подробно педагогические взгляды о воспитании патриотизма человека виднейших представителей педагогической мысли России XIX века.

В.Г. Белинский уделял большое внимание патриотическому воспитанию. Критериями воспитанности он считал гражданственность, любовь к своему Отечеству, патриотизм, активную жизненную позицию по улучшению жизни в своей стране, вера в высокое предназначение человека, человеческое достоинство. Любовь к Отечеству соотносится у В.Г. Белинского с любовью к человечеству [6].

Воспитание истинных патриотов своего отечества рассматривалось В.Г. Белинским как одна из самых важных задач школы. Очень ценную и очень важную в жизни нравственную черту нового человека - активного общественного деятеля, гражданина своего отечества - В.Г. Белинский видел «в твердом, глубоком убеждении, в пламенной, непоколебимой вере в достоинство человека, в его высокое назначение» [6]. Ему хотелось, чтобы каждый ребенок был достаточно подготовлен к тому, чтобы в течение всей своей жизни с честью нести высокое назначение человека, чтобы он ни на минуту не терял своего человеческого достоинства, неизменно уважал и в меру своих сил поддерживал достоинство других людей [6].

Для Н.Г. Чернышевского существенным является вопрос о целях воспитания человека. Он был сторонником идеи воспитания человека-борца, революционера. Приоритет он отдавал воспитанию в человеке альтруизма, т.е. воспитание человека, живущего для блага других людей, активно участвующего в гражданских делах исключительно во имя общей пользы: 
«...лучше не развиваться человеку, нежели развиваться без влияния мысли об общественных делах, без влияния чувств, пробуждаемых участием в них... если из ....сферы действий, в которой вращаюсь я, исключены идеи и побуждения, имеющие предметом общую пользу, то есть исключены гражданские мотивы, что останется наблюдать мне?» [7, С.57].

Н.А. Добролюбов указывал, что необходимо воспитывать активного общественного деятеля, человека, стремящегося жить во благо Родины, во благо общества, в котором они живут. Патриотическое воспитание, по словам Н.А. Добролюбова, является одним из главных условий развития ребенка и включает в себя активную деятельность в борьбе за народное благо, включающий гражданский героизм, самопожертвование личным благом ради общественного интереса [8].

Н.А. Добролюбов говорил: «...в человеке порядочном патриотизм есть не что иное, как желание трудиться на пользу своей страны и происходит не от чего другого, как от желания делать добро» [8, С.135].

Н.И. Пирогов в своих работах выражает мысль о том, что от воспитания патриотизма зависит будущее не только конкретного человека, но и всего человеческого рода, и поэтому на воспитание поколения нужно уделять особое внимание. Он в своих работах намечает путь совершенствования общества от поколения к поколению путем самосовершенствования духовного мира каждого человека, а фактором самосовершенствования человека является воспитание и самовоспитание в индивиде патриотизма [9].

К.Д. Ушинский приоритетным направлением воспитания считал патриотическое воспитание. Он говорил о том, что, каким бы умным человек не был, как бы не были развиты его умственные способности, но если у человека не будет развита любовь к ближнему и готовность оказать ему помощь и поддержку; не будет развита любовь к Родине; не будет развита активная трудовая деятельность во благо народа, то умственные способности человека обратятся во вред и человеку, и обществу в целом [10].

Исследуя воспитательные системы различных стран, К.Д.Ушинский выявил общие черты систем и пришел к выводу, что они включают исторически сложившиеся черты характера народа страны, его склонности и потребности, что составляют народность. Народность он считал основой патриотического воспитания. Приписывание системе воспитания универсального, общечеловеческого характера К.Д. Ушинский считал 


\section{ИННОВАЦИОННОЕ РАЗВИТИЕ НАУКИ: ФУНДАМЕНТАЛЬНЫЕ И ПРИКЛАДНЫЕ ПРОБЛЕМЫ}

несостоятельной, не имеющей под собой реальной основы. Он считал, что России присущи свои особенности, которые и должны составлять основание системы воспитания: чувство любви к родине, высокий патриотизм и сомоотверженность, гражданственность.

Анализируя ценности идеала воспитания человека ХІХв. в трудах В.Г. Белинского, Н.А. Добролюбова, Н.И. Пирогова, К.Д. Ушинского, Н.Г. Чернышевского, можно сделать вывод, что основополагающими ценностями являлись: уважение к своему народу; любовь к Родине; любовь к человечеству; справедливость и честность; гражданственность и человечность; скромность, ответственность за свои слова и поступки; альтруизм, активная деятельность в борьбе за народное благо, гражданский героизм, самопожертвование личным благом ради общественного интереса. Имея основополагающие ценности патриотического воспитания предыдущих эпох, современный идеал воспитания человека вбирает в себя патриотические ценности современной эпохи.

Рассматривая патриотическое воспитание, осуществляемое в XX веке в CCCP, важно отметить, что патриотическому воспитанию уделялось значительное внимание. На формирование патриотизма влияли СМИ, культура, искусство, литература, поэзия, театральная деятельность, киноиндустрия, развитая кружковая система по изучению военного дела, военно-спортивные комплексы, одним из которых был спортивный комплекс «Готов к труду и обороне».

В СССР на первом плане стояли не личные, а общественные интересы. Современные исследователи истории отечественной педагогики такие, как М.Г. Плохова, В.Т. Пряникова, 3.И. Равкин, Л.А. Степашко, Ф.А. Фрадкин и др. называют 20-30 гг. ХХ в. в СССР периодом «гражданского ренессанса».

Деятельность СССР в течение всего периода своего существования (с 30 декабря 1922 г. по 26 декабря 1991 г.) была направлена на сплочение, консолидацию и укрепление народа.

Государственные структуры, образовательные и общественные организации эффективно добивались успехов в воспитании патриотов. Особенно большое внимание уделялось воспитанию патриотизма в рамках общеобразовательных организаций (в школах, в высших учебных заведениях). Целая плеяда педагогов периода СССР работала в данном направлении: П.П. Блонский, И.Д. Бех, И.П. Иванов, Е.Н. Ильин, Н.К. Крупская, 
С.И. Лысенкова, А.С. Макаренко, В.А. Сухомлинский, В.А. Сластёнин,
В.Ф. Шаталов, С.Т. Шацкий и др.

П.П. Блонский [11] считал, что самовоспитание и саморазвитие лучше всего поможет человеку стать достойной личностью и гражданином. Поэтому не нужно доказывать чужую точку зрения в определённом вопросе, а лишь помогать человеку в развитии своей позиции, в самопознании, в укреплении совести, чести, долга и достоинства личности юного гражданина.

А.С. Макаренко считал главной воспитательной задачей научить жить молодое поколение интересами народа. В этом он видел проявление патриотизма. А.С. Макаренко понимал под патриотизмом не только геройские поступки, направленные на укрепление родной страны, но и трудовой героизм, беззаветная трудовая деятельность во благо народа, во благо будущего страны.

Н.К. Крупская подчеркивала важность патриотического воспитания молодёжи, призывала изучать деятельность лидеров молодого Советского государства, на их примере воспитывать патриотизм [12].

Н.К. Крупская ввела понятие «военное воспитание», под которым в настоящее время подразумевается военно-патриотическое воспитание. Она призывала уделять огромное внимание воспитанию патриотизма у подрастающего поколения, который заключался не только в беззаветном служении Родине, геройских поступках на военном поприще, но и в геройстве трудовом, в трудовой деятельности во благо своего народа, во благо достижения глобальной цели государства: построение коммунизма.

Большой вклад в патриотическое воспитание сделал С.Т. Шацкий в плане внедрения идеи экскурсионной и краеведческой патриотической деятельности. Основой развития патриотического воспитания он считал трудовую деятельность. С.Т. Шацкий считал, что труд является неким нравственным развивающим аспектом воспитания патриотизма у подрастающего поколения, любви к родному краю.

В.А. Сухомлинский говорил о том, что воспитание чувства долга перед самым дорогим и святым - Родиной - это любовь к родным [13]. Он говорил о том, что в основании патриотизма лежит радость творения, радость создания красоты в самом себе, питающая своими животворными соками большое патриотическое чувство, эта радость начинается с творения добра для матери и отца, дедушки и бабушки - для того, кто тебя породил, вскормил и 
взлелеял... От людей родных и близких, от духовного общения с ними юный гражданин приходит к понятию соотечественник, к великому представлению о Родине.

В.А. Сухомлинский писал: «Я стремлюсь к тому, чтобы уже в годы детства в сознании каждого маленького гражданина утверждалась нерушимая, незыблемая, непреложная вера в нравственные святыни нашего Отечества, народа. Но ни во что не верящий человек не может быть ни духовно сильным, ни нравственно чистым, ни мужественным» [13].

В.А. Сухомлинский подчёркивал: «Это живая плоть и кровь нравственности. Я стремился к тому, чтобы воспитанники не только знали, понимали добро и зло, справедливость и несправедливость, честь и бесчестье, но и переживали непримиримость к социальному злу, бесправию, бесчестью... Чтобы мои рассказы о мире не только доносили знания до сознания мальчиков и девочек, но и заставляли задуматься над судьбой мира, над тем, что мое личное счастье, счастье семьи зависят от чего-то более значительного, нежели огород и приусадебный участок, урожай яблок в нынешнем году и цена на них...» [14].

Невероятный подвиг народа во время Отечественной войны показал, как выросла гражданская ответственность и патриотизм молодого поколения за годы советской власти, и стал источником поддержания патриотизма в 19601970 годах.

В 1991 году, после распада СССР, патриотическое воспитание подрастающего поколения пришло в глубокий кризис, который продолжается и по настоящее время.

В условиях рыночной экономики ведущим мотивом поведения людей стало обогащение. Платные учебные заведения, военная служба по контракту сводят патриотическую работу как таковую на нет. Духовность отходит на второй план. Грубо нарушаются конституционные требования относительно обязательности общего среднего образования.

За последние годы в современной России были предприняты различные меры по поднятию уровня патриотизма у молодёжи.

Формирование патриотизма оглашается в нормативно-правовых актах, в государственных программах и проектах.

Для поднятия уровня патриотизма в настоящее время проводятся военно-патриотические мероприятия, такие как «Зарница», «Орленок» и др. С 
1 сентября 2014 года вступил в силу Указ Президента Российской Федерации от 24 марта 2014 года № 172 «О Всероссийском физкультурно-спортивном комплексе «Готов к труду и обороне» (ГТО)».

Увеличилось количество организаций дополнительного образования патриотической направленности, что постепенно ведёт к поднятию патриотизма у молодёжи. Так, в 2012 году данных организаций насчитывалось 8386, в 2014-11776, в 2018-17456, в 2019 - 19547.

В 85 субъектах РФ созданы организации по военно-спортивному образованию.

В образовательных организациях реализуются программы, наиболее эффективные для подготовки учащихся к военной службе. Так, в 2015 г. в системе образования функционируют 177 кадетских учреждений, в 2018 г. -335 учреждений, в 2019 г. - 446 учреждений.

По данным социологичеких исследований, граждане, которые участвуют

в мероприятиях по патриотическому воспитанию или допризывной подготовки молодежи составляет $22,5 \%$ от общего количества граждан в Российской Федерации.

По данным социологических опросов, на настоящий момент чувство патриотизма испытывают 92\% граждан Российской Федерации. Но при этом респонденты разошлись в мнении о том, что значит быть истинным патриотом. Так, 59\% респондентов заявили, что патриотизм проявляется в любви к своей стране (в 2014 году так ответили 72\% участников опроса). Более трети россиян (39\%) считают патриотизмом стремление к изменению положения дел в стране (в 2014 году - 34\%).

Рассматривая суть понятия «патриотизм» в историческом аспекте, можно сказать, что различные мыслители уделяют данному понятию большое внимание. Структура понятия «патриотизм» имеет далеко не одинаковую трактовку в педагогической литературе.

Так, В.И. Даль, известный русский писатель, этнограф и лексикограф, рассматривает патриотизм через объяснение понятия патриот: патриот любитель Отечества, ревнитель о благе его; патриотизм, как любовь к Отчизне [15].

В словаре С.И. Ожегова даётся определение патриотизма, как преданность и любовь к своему Отечеству, к своему народу [16]. 


\section{ИННОВАЦИОННОЕ РАЗВИТИЕ НАУКИ: ФУНДАМЕНТАЛЬНЫЕ И ПРИКЛАДНЫЕ ПРОБЛЕМЫ}

В педагогическом словаре «патриотизм» определяется как «чувство любви к своему Отечеству, готовность подчинять свои личные и групповые интересы общим интересам страны, верно служить ей и защищать ее» [17].

И.Д. Бех считает, что воспитание патриотизма подразумевает как широкие знания конституционных и правовых норм, государственной политики, сформированность патриотических мыслей и действенных мер по отстаиванию национальных форм жизнедеятельности и поведения во всех сферах общественной жизни. Настоящее патриотическое воспитание начинается там, где идея и личный труд - пот, мозоли, сливаются воедино, создают то, о чем народ говорит: у человека есть святое за душой - говорил И.Д. Бех [18].

С точки зрения Н.А. Сиволобовой, патриотизм - это любовь к своему отечеству; к родным местам, к родному языку, к культуре и традициям, к прогрессивному общественному и государственному строю. Патриотизм это беззаветная преданность своей Родине, готовность защищать ее независимость, уважение к своим предкам, готовность улучшать свой край, проявление терпимости к землякам [19].

И.Ф. Харламов понимает патриотизм, как бережное отношение к историческим памятникам и обычаям родной страны, привязанность и любовь к родным местам; стремление к укреплению чести и достоинства Родины, готовность и умение защищать ее, храбрость, мужество и самоотверженность, нетерпимость к расовой и национальной неприязни, уважение обычаев и культуры других стран и народов [20].

Г. Ефремова раскрывает понятие патриотизма, как любовь к своему отечеству, преданность народу; высшая проявленность человеческого духа [21].

3.T. Гасанов рассматривает патриотизм «как национальное воспитание, то есть воспитание в духе ментальности народа, его кордоцентризма, тяге к прекрасному и стремление к гармонии» [22].

Таким образом, в современной педагогической науке патриотическое воспитание понимается как эмоциональное, нравственное и действенное отношение к себе и другим людям, к родной природе, к своей нации, к духовным ценностям своего народа, к своему менталитету. Патриотизмом является возвышенное чувство любви к народу и Отечеству, стремление к укреплению чести и достоинства совей страны. 
Нравственные качества личности, определяющие ее направленность на патриотизм, с нашей точки зрения, подразделяются на три группы, характеризующие отношения человека к самому себе, другим людям и обществу, к различным видам деятельности. Патриотизм - это сложное, многогранное интегральное качество, охватывающее все эти три группы, проявляющиеся в отношении личности к людям, обществу, труду и другим видам деятельности, к материальным ценностям и формирующееся в процессе реализации различных видов деятельности.

В современной России большое влияние уделяется патриотическому воспитанию человека, поднятию уровня патриотизма, духа народа и нации. Деятельность государства направлена на сплочение и укрепление народа. Благодаря различным мероприятиям у молодёжи формируется чувство патриотизма, любовь к Родине, уважение к героям войны и труда.

С нашей точки зрения, совершенствование патриотического воспитания молодёжи следует осуществлять:

- путём развития в обществе высокой социальной активности, гражданской ответственности, духовности;

- путём становления гражданского общества, состоящего из граждан, обладающих высоким сознанием и способностью проявить ее в повседневной деятельности по обеспечению устойчивого развития;

- утверждение в обществе уважения к истории России;

- более активного вовлечения молодёжи в решение социальноэкономических, культурных, правовых, экологических и других проблем;

- воспитания у молодёжи законности, направленности на поддержание норм общественной и коллективной жизни;

- создание условий для обеспечения реализации конституционных прав человека и его обязанностей;

- создание условий для обеспечения реализации гражданского и профессионального долга;

- развитие чувства гордости, глубокого уважения к символам государства — Гербу, Флагу, Гимну;

- развитие глубокого уважения к символике и историческим святыням, и на этой основе воспитание гордости за свою страну; 


\section{ИННОВАЦИОННОЕ РАЗВИТИЕ НАУКИ: ФУНДАМЕНТАЛЬНЫЕ И ПРИКЛАДНЫЕ ПРОБЛЕМЫ}

- создание условий для усиления патриотической направленности средствами массовой информации при освещении событий и явлений общественной жизни;

- активное противодействие антипатриотизму, манипулированию информацией;

- формирование расовой, национальной, религиозной терпимости, развитие дружеских отношений между представителями различных этнических групп.

Что касается воспитания патриотизма у молодёжи, то, по нашему мнению, патриотическое воспитание необходимо проецировать по следующим направлениям:

1. Историко-патриотическое направление имеет целью знание исторического прошлого России: сохранение и следование трудовым, культурным, духовным традициям русского народа, воспитание на этой основе гордости за свою страну и ее исторические достояния; осознание памятных событий, знание памятных мест, выдающихся общественных и политических деятелей и их дел; празднование памятных дат в жизни родного города (основания, оборона от врагов, культурное и политическое развитие); походы и экскурсии по памятным историческим местам.

2. Героико-патриотическое направление имеет целью формирование готовности к подвигу во имя Родины, в том числе - к самопожертвования ради жизни следующих поколений: осознание истоков героического - любовь к Родине, ее народу; личная ответственность за её судьбу; знание памятных мест освободительных боев, походы и экскурсии по местам боевой славы; Книга Памяти, Книга Скорби, Хрестоматии Подвига российского народа в борьбе за свою независимость.

3. Физическое направление имеет целью формирование здоровья нации: привлечение граждан к регулярным занятиям физической культурой и спортом; направленность физического воспитания на подготовку к труду и защите Отечества; развитие общественного спортивного движения.

4. Военно-патриотическое направление имеет целью: формирование патриотических чувств в соответствии с требованиями Конституции России и готовности к службе в войсках России; стремление к овладению военными знаниями, соответствующего уровня физической подготовки и закалённости в интересах защиты Отечества; повышение престижа военной службы, военная 
профессиональная ориентация; формирование и развитие мотивации, направленной на подготовку к защите государства в Вооружённых Силах и других военных формированиях; формирование способностей к анализу внешней и внутриполитической обстановки, умение на этой основе самостоятельно адекватно оценивать события, происходящие в государстве и мире, свою роль и место в этих событиях.

С учётом особенностей патриотического воспитания в современном обществе целью данного процесса является воспитание убеждённого патриота, любящего свою Родину, преданного Отечеству, готового служить ему своим трудом и защищать его интересы.

В соответствии с заданными направлениями воспитания патриотического воспитания и целью, в настоящее время превалируют такие задачи патриотического воспитания молодёжи, как:

- формирование чувства патриотизма;

- развитие и расширение знаний об истории России;

- становление многогранного развитого гражданина России в культурном, нравственном и физическом отношениях;

- развитие интереса и почитания культуры и истории различных народов Российской Федерации;

- воспитание чувства любви к семье, родному краю, истории;

- формирование интереса к русским традициям и промыслам;

- формирование элементарных знаний о правах человека;

- развитие чувства гордости за достижения Отечества;

- формирование толерантности к другим людям, народам и традициям.

Основные руководящими положениями при этом являются: гуманизм, научность, важность исторического и культурного наследия Российской Федерации, ее традиций и духовных ценностей, преемственности в развитии молодежи с учетом возрастных особенностей и интересов [8].

Воспитание патриотизма у молодёжи опирается на некоторые принципы. Основными принципами патриотического воспитания человека являются [4]: 
- принцип системно-организованного подхода, предусматривающего целенаправленную работу всех государственных и общественных структур по патриотическому воспитанию человека в Российской Федерации;

- принцип адресного подхода в формировании патриотизма, направленного на применение особых форм и методов патриотической работы с учетом возрастной, социальной, профессиональной и других групп населения;

- принцип активности, предполагающего трансформацию мировоззрения человека и его ценностных установок, ориентированных на национальные интересы;

- принцип универсальности основных направлений патриотического воспитания человека, предполагающего воспитание чувства гордости за своих предков, национальные традиции в быту;

- принцип учета региональных условий в пропаганде патриотических идей и ценностей человека, предполагающего передачу идей и ценностей патриотизма.

Исходя из установок, цели, задач, принципов определяется содержание, формы, методы, средства патриотического воспитания.

Содержанием патриотического воспитания являются ценности, хранимые в культурных, семейных, этических и социальных традициях, многие ценности выходят ещё из детства и передаются из поколения в поколение.

Традиционными источниками ценностного аспекта патриотического воспитания, с нашей точки зрения, являются:

1. Патриотизм человека, проявляющийся в любви к Родине и готовности пожертвовать своими интересами ради неё.

2. Социальная солидарность - единство (группы или класса), которое порождает единство интересов, задач, стандартов и взаимопонимание, или же основывается на них.

3. Гражданственность, осознание человеком принадлежности к обществу, в котором он живёт, в осознании прав, обязанностей по отношению к обществу, знание и умение соблюдать нормы морали и закон.

4. Честь - достойные уважения и гордости моральные качества человека; его соответствующие принципы. 
5. Доверие - открытые, положительные взаимоотношения между людьми, содержащие уверенность в порядочности и доброжелательности другого человека, с которым доверяющий находится в тех или иных отношениях.

6. Государственная символика: гимн, герб, флаг;

7. Права человека и гражданина.

Процесс интериоризации базовых ценностей патриотизма человека в личностные ценностные смысловые категории и ориентиры требует включения в ситуацию выбора для себя смысла ценностей, определения собственного отношения к ней, формирования опыта созидательной реализации этих ценностей на практике.

Формы патриотического воспитания должны реализовываться системно, с определённой цикличностью, в соответствии с научно обоснованными организационными условиями, способствующими решению основных задач воспитания патриотизма.

Основными формами патриотического воспитания молодёжи являются:

- информационно-массовые (дискуссии, диспуты, конференции);

- деятельностно-практические (краеведческая деятельность, походы по родному краю, экскурсии в музеи, театрализация, кружковая деятельность);

- интегративные;

- индивидуальные.

Патриотическое воспитание может осуществляться через применение различных комплексных комбинированных интегрированных форм, оптимально сочетающих как общее, так и специфическое в его содержании.

Эффективность форм патриотического воспитания достигается за счет разумного их сочетания, учета возрастных, индивидуальных особенностей, уровня развития и воспитанности субъектов воспитания.

В высших учебных заведениях в рамках патриотического воспитания могут реализоваться такие формы осуществления патриотического воспитания, как:

- проведение конференций, семинаров, встреч с ветеранами войн;

- организация конкурсов плакатов, стенных газет;

- проведение экскурсий на патриотическую тематику; 


\section{ИННОВАЦИОННОЕ РАЗВИТИЕ НАУКИ:

- создание альбомов памяти (войны, великие герои);

- проведение военно-спортивных мероприятий;

- проведение различных концертов (День Победы, принятие Конституции и т.д.);

- создание тематических общественных объединений;

- создание общественных молодёжных движений, направленных на формирование патриотического духа молодёжи.

Говоря о средствах патриотического воспитания, можно обратить внимание на такие средства, как родной язык, изучение истории народа, краеведение, изучение народной мифологии, фольклора, национального искусства, национальной символики, народных верований, национальных традиций, обычаев и обрядов.

С нашей точки зрения, эффективность патриотического воспитания субъектов воспитания зависит от ряда факторов:

- опора на инновационные концепции организации и осуществления воспитательного процесса;

- опора на положительное в личности воспитанника;

- создание благоприятной психологической атмосферы в процессе педагогического взаимодействия;

- координация взаимодействия вуза, семьи и общественности в системе патриотического воспитания.

В целом, задача педагога состоит в том, чтобы создать благоприятные условия для воспитания достойного гражданина.

Исходя из практики, можно выделить некоторые условия воспитания патриотизма у субъектов воспитания:

- личный пример социально-значимой личности (родственник, куратор, педагог по воспитательной работе, преподаватель и т.д.). В условиях информационной нестабильности требуется высоконравственный образ человека, который мог бы в течение длительного времени сформировать мировоззрение, отношение к миру, к своему государству;

- активизация деятельности субъектов воспитания в учебной и внеучебной деятельности (проведение различных мероприятий по воспитанию патриотизма);

- приобщение субъектов воспитания к традициям вуза. 
Изученные идеи патриотического воспитания молодёжи актуальны для современного общества. Патриотизм как социальное явление, является фундаментом для существования нации и государства.

Патриотическое воспитание характеризуется появлением своеобразного мотивационного кризиса, который вызван потребностью в самосовершенствовании. Благодаря хорошей информированности о патриотическом воспитании молодые люди могут трансформировать и моделировать собственную деятельность.

Действительно, патриотическое воспитание - было, есть и будет одной из актуальных задач современного общества. В современном мире, в условиях быстроменяющейся ситуации в государстве, патриотическое воспитание является необходимым условием развития государства. Каждому человеку необходимо знать историю родного края и традиции своего Отечества.

Говоря о воспитании патриотизма у субъектов воспитания, мы должны в первую очередь заботиться о том, чтобы воспитать истинных патриотов, стремящихся к созиданию, самоопределению и развитию в себе тех качеств и ценностей, благодаря которым мы с уверенностью скажем о них, что они истинные патриоты и граждане своей Родины.

Патриотическое воспитание представляет собой формирование активной гражданской позиции, любви к своей Родине, осознания собственного места в обществе. Это беспрерывная работа, направленная на воспитание гордости за свой народ и свою страну, уважения к достойным страницам ее прошлого.

Исходя из вышесказанного, можно сказать, что воспитание патриотизма у молодёжи становится всё более актуальным. Тот факт, что педагоги в рамках образовательного учреждения, как никто другой, способны существенно повлиять на формирование личности человека и воспитать его достойным гражданином, доказали в своё время многие известные педагоги, такие, П.П. Блонский, Н.К. Крупская, А.С. Макаренко, В.А. Сухомлинский, К.Д. Ушинский и др. Они внесли огромный вклад в развитие патриотического воспитания в нашей стране подробно описав методики гражданского воспитания.

Воспитательная система имеет огромное количество связей и отношений с окружающей социальной средой. Расширение воспитательного 
пространства обеспечивается в данной системе за счет связей с учреждениями и общественными организациями.

Воспитанию любви и бережного отношения к родной земле - своей малой Родины, ее истории, уважения народных традиций и обычаев, обрядов, фольклора, любви к родной природе должно уделяться значительное внимание.

Чтобы по-настоящему любить родной край, его надо хорошо знать, необходимо изучать его историю, язык, культуру, что ведёт к формированию патриотизма у молодёжи.

Национальное осознание российского патриотизма требует утверждения гражданских чувств, российской национальной гордости и человеческого достоинства гражданина России, государственной идеи, переживания за судьбу российского государства, готовности стать на защиту независимости России.

С целью воплощения идеи государственности нужно информировать молодёжь о важнейших общественно-политических и экономических событиях в России и за рубежом. Всё воспитательное воздействие необходимо направлять на возрождение нации, на воспитание высокого гражданского чувства принадлежности к Родине, ее народу.

Таким образом, предметом внимания патриотического воспитания молодёжи должна стать национальная идея, национальная культура, родной язык, история народа и государства, самоопределение, самоидентификация, категории Родины (малая и большая Родина), лидеры и герои народа, нации, государства, родного края.

Во все времена каждое государство мира с момента своего создания заботилась о соответствующей подготовке патриотичного подрастающего поколения своих граждан. Обретение Россией статуса независимого государства поставило перед обществом задачу создать эффективную систему национального воспитания молодежи, одним из главных направлений которой является патриотическое воспитание. Реализация данной задачи с первых дней была осложнена различием региональных подходов к трактовке отечественной истории, языкового вопроса, национальной идеи, национальным, религиозным и идеологическим многообразием населения нашей страны. Очень быстро к этому добавились растущее обострение проблем социально-экономического развития, резкое имущественное 


\section{ИННОВАЦИОННОЕ РАЗВИТИЕ НАУКИ: ФУНДАМЕНТАЛЬНЫЕ И ПРИКЛАДНЫЕ ПРОБЛЕМЫ}

расслоение общества, обесценивание моральных норм и ценностей, формирование патриотического нигилизма и преувеличенного проявления национализма.

Учитывая эти факторы, возникает острая проблема необходимости активизации патриотического воспитания молодёжи, целью которого должно стать создание основы их гражданской позиции.

Педагогическое наследие по данной проблеме актуализирует современные взгляды педагогов на эту проблему.

О выполнении мероприятий патриотического воспитания говорит его действенность на фоне системных проявлений равнодушия, социального эгоизма, цинизма, немотивированной агрессивности и жестокости, неуважительного отношения к праву, государственным и социальным институтам, коррупции, продолжение противостояния в оценке отечественной истории и других негативных явлений общественной жизни.

Вместе с тем, следует отметить, что педагогами нашей страны постепенно накапливается значительный практический педагогический опыт патриотического воспитания. Эта работа ведется на концептуальной основе российского патриотизма и национальной идеи.

Таким образом, можно сделать вывод, что совершенствование патриотического воспитания молодёжи следует осуществлять путем развития у них высокой социальной активности, гражданской ответственности, духовности. Необходимо более активно вовлекать молодёжь в решение социально-экономических, культурных, правовых, экологических и других проблем; воспитывать у них стремление к законности, направленность на поддержание норм общественной и коллективной жизни; способствовать созданию условий для обеспечения реализации конституционных прав человека и его обязанностей, гражданского и профессионального долга.

Необходимо способствовать становлению у молодёжи мотивации к развитию гражданского общества; становлению высокого гражданского сознания и способности проявить его в повседневной деятельности; воспитывать у них уважение к истории России; развивать чувство гордости за героическое прошлое своей страны, воспитывать уважение к символике патриотизма и к историческим святыням народа; активно противодействовать антипатриотизму, манипулированию информацией; способствовать формиро- 
ванию расовой, национальной, религиозной терпимости, развивать дружеские отношения между представителями различных этнических групп.

\section{Список литературы}

1. Нормативные документы об образовании в России. [Электронный pecypc] [https://edu.garant.ru/education/law/] (Дата обращения: 22.10.2019).

2. Аронов А.А. Воспитывать патриотов. Книга для учителя. - М.: Просвещение, 2014. - 175c.

3. Гриценко Л.И. Теория и методика воспитания: личностносоциальный подход / Л. И. Гриценко. - М. : Академия, 2014. - 240с.

4. Попова В.А. Формирование гражданской позиции воспитанников через различные виды деятельности. [Электронный ресурc] [https://www. maam.ru/detskijsad/-formirovanie-grazhdanskoi-pozici-vospitanikov-cherez-razlich nye-vidy-dejatelnosti-opisanie-opyta-raboty.html] (Дата обращения: 10.11.2019).

5. Суколенов И.В. Теория и практика гражданского образования в общеобразовательных учреждениях (Историко-педагогические аспекты): Дис.д-ра пед.наук. - М., 2014.

6. Белинский В. Г. Полное собрание сочинений, т. V, изд. АН СССР, 1954. - 489c.

7. Белинский В. Г. Полное собрание сочинений, т. V, изд. АН СССР, 1954. -489 c.

8. Белинский В. Г. Полное собрание сочинений, т. V, изд. АН СССР, 1954. - 489c.

9. Пирогов Н.И. Избранные педагогические сочинения / Сост. А.Н.Алексюк, Г.Г. Савенок. - М.: Педагогика, 1986. - 379c.

10. Ушинский К. Д. Собрание сочинений, т. 2, изд. АПН РСФСР, 1948. $-346 \mathrm{c}$.

11. Турич И.М. Труды П.П.Блонского. [Электронный ресурс] [http://pedagogic.ru/books/item/f00/s00/z0000045/st035.shtml] (Дата обращения: 21.11.2019).

12. Смирнов И.Н. Педагогическая концепция и практика Надежды Константиновны Крупской. [Электронный ресурс] [https://www.bibliofond.ru/ view.aspx?id=652809] (Дата обращения: 21.11.2019). 
13. Сухомлинский В. А. Избранные педагогические сочинения : в 3-х тт. Т. 1 / В. А. Сухомлинский ; сост. О. С. Богданова, В. 3. Смаль. - Москва : Педагогика, 1979. - 320с.

14. Сухомлинский В.А. Сердце отдаю детям. Автор: Р.И. Землин [Электронный pecypc] [http://pedlib.ru/Books/1/0214/1_0214-137.shtml] (Дата обращения: 22.11.2019).

15. Толковый словарь Даля онлайн. [Электронный ресурс] https://www.slovardalja.net/ (Дата обращения: 03.05.2020).

16. Ожегов С.И.: Толковый словарь русского языка. М.: Оникс - 2008 г. $534 \mathrm{c}$.

17. Педагогический энциклопедический словарь. [Электронный ресурс] https://slovar.cc/enc/ped/2137830.html (Дата обращения: 05.05.2020).

18. Бех И.Д. Программа патриотического воспитания детей и учащейся молодежи. - М .: Институт проблем воспитания АПН Украины, 2006. - 58c.

19. Сиволобова Н.А. Гражданско-патриотическое воспитание учащейся молодежи: опыт и инновации : монография. - Ставрополь: Изд-во СГПИ; Дизайн-студия Б, 2017. - 136 с. ISBN 978-5-9500789-9-6B

20. Харламов И. Ф. Педагогика. - М.: Гардарики, 1999. - 520с.

21. Ефремова Г. Патриотическое воспитание школьников // Воспитание школьников - 2013 № 8 - С.17-20.

22. Гасанов 3.Т. Цель, задачи и принципы патриотического воспитания граждан [Электронный ресурс]: электрон. данные. - Москва: Научная цифровая библиотека PORTALUS.RU, 30 октября 2007. - Режим доступа:https://portalus.ru/modules/shkola/rus_readme.php?subaction=showfull\&i $\mathrm{d}=1193750320 \&$ archive $=1194448667 \&$ start_from=\&ucat=\& (свободный доступ). (Дата обращения: 03.05.2020). 